\title{
PReS-FINAL-2007: Adolescent clinic for young patients with juvenile idiopathic arthritis
}

\author{
SK Sørensen \\ From 20th Pediatric Rheumatology European Society (PReS) Congress \\ Ljubljana, Slovenia. 25-29 September 2013
}

\section{Introduction}

Parents are very involved in the treatment and care of their child with juvenile idiopathic arthritis (JIA). As the child grows older, the dynamics in the family should change by the parents moving into the background and the adolescents gradually taking over the responsibility for the treatment and care.

It may be a challenge for the adolescent, the parents and the health care professionals to make the adolescent more involved and to make the parents gradually withdraw.

\section{Objectives}

The purpose is to increase focus on the individual adolescent. Through teaching, the young patient will gradually be prepared to take responsibility and gain knowledge of the disease, treatment and its influence on their future.

Also the parents will slowly hand over the responsibility to the acolecent.

\section{Methods}

An adolescent clinic for patients aged 12-15 years will be established.

\section{Results}

The adolescents are expected to gain a greater understanding of their disease. The adolescents will gradually be introduced to take over the responsibility for their treatment through learning about the disease, the treatment, the impact of the disease on their everyday life and the future. Concurrently, the parents will be supported in handing over the responsibility to their adolescent.

\footnotetext{
Peadiatric Department A3, Aarhus University Hospital, Aarhus N, Denmark
}

\section{Conclusion}

The transfer from pediatric to adult department will occur smoothly and the experience of transition will improve. The young patients will experience a more youth-oriented approach to their disease and treatment. Which will benefit the transition from childhood to adulthood with JIA.

\section{Disclosure of interest}

None declared.

Published: 5 December 2013

doi:10.1186/1546-0096-11-S2-P20

Cite this article as: Sørensen: PReS-FINAL-2007: Adolescent clinic for young patients with juvenile idiopathic arthritis. Pediatric Rheumatology 2013 11(Suppl 2):P20.
Submit your next manuscript to BioMed Central and take full advantage of:

- Convenient online submission

- Thorough peer review

- No space constraints or color figure charges

- Immediate publication on acceptance

- Inclusion in PubMed, CAS, Scopus and Google Scholar

- Research which is freely available for redistribution
() Biomed Central 